\title{
Malignant Mesothelioma in Cappadocia: Data from Eight Regional Hospitals
}

\author{
Kapadokya Bölgesindeki Mezotelyoma: Sekiz Bölgesel Hastane Verileri
}

\author{
(D) Ipek Pınar Aral1', (1) Mehmet Beșiroğlu², (1) Süheyla Aytaç Arslan³ \\ ${ }^{1}$ Nevşehir State Hospital, Clinic of Radiation Oncology, Nevşehir, Turkey \\ 2Bezmialem University Faculty of Medicine, Department of Medical Oncology, İstanbul, Turkey \\ ${ }^{3}$ Ankara City Hospital, Clinic of Radiation Oncology, Ankara, Turkey
}

\begin{abstract}
Introduction: This study aimed to describe the current situation of malignant mesothelioma (MM) by examining data from 8 state hospitals in Cappadocia, where one of the most serious mesothelioma endemics is observed. Recently, no assessment of this endemic has been conducted in Cappadocia. Therefore, this study aimed to provide up-to-date information regarding the current situation.

Methods: Patients with pleural or peritoneal MM admitted to local state hospitals in Cappadoccia between 01.01.2007 and 25.09.2019 were retrospectively evaluated. The primary endpoint of the study was the overall survival (OS). The secondary endpoint was the evaluation of the current status of MM cases in Cappadocia and the determination of patients' access to health care.
\end{abstract}

Results: Seventy-one patients were retrospectively evaluated. The median follow-up period was 26 months (range: 1-153); 55 patients (77.5\%) died, while 16 patients (22.5\%) survived. Sixtysix (93\%) patients were diagnosed with pleural MM and $5(7 \%)$ patients were diagnosed with peritoneal MM. It was observed that 18 (25.4\%) of the patients resided in Sarıhıdır, Karain and Tuzköy, which was the decision to evacuate. Median OS was 16 months (range: 1-133) for pleural MM and 21 months (range: 9-117) for peritoneal MM. Significantly higher OS was observed in patients aged 60 years or less at the time of diagnosis $(p=0.014)$. Only 6 patients $(8.5 \%)$ were diagnosed at Nevșehir Hospital and $91.5 \%$ of 65 patients were diagnosed outside the Cappadoccia.

Conclusion: The current situation of MM in Cappadocia was evaluated in this study. The OS of MM patients has not changed dramatically in the last 30 years. Approximately $90 \%$ of patients had to move out of the province for diagnosis and treatment. Further studies are needed to evaluate the current situation and treatment outcomes in this region.

Keywords: Cappadocia, malignant pleural mesothelioma, malignant peritoneal mesothelioma

\section{öZ}

Amaç: Bu çalışmanın amacı dünyanın en büyük mezotelyoma endemilerinden birine sahip olan Kapadokya'daki 8 devlet hastanesinin verilerini inceleyerek malign mezotelyomanın (MM) mevcut durumu hakkında bilgi vermektir. Son dekattır Kapadokya bölgesindeki endemi hakkında değerlendirme yapılmamış olup, çalışmamızda güncel durum hakkında bilgi vermek amaçlanmıştır.

Yöntemler: Kapadokya'daki yerel devlet hastanelerine 01.01.2007 ile 25.09.2019 tarihleri arasında başvuran plevral MM veya peritoneal MM hastaları retrospektif olarak değerlendirildi. Çalışmanın birincil sonlanım noktası genel sağkalım (OS) idi. Íkincil sonlanım noktası, Kapadokya'daki MM olgularının mevcut durumunun değerlendirilmesi ve hastaların sağ ık hizmetlerine erişiminin belirlenmesi idi.

Bulgular: Çalıșmamızda 71 hasta retrospektif olarak değerlendirildi. Medyan takip süresi 26 ay (aralık: 1-153) idi ve 55 hasta $(\% 77,5)$ öldü, 16 hasta $(\% 22,5)$ hayattaydı. Altmış altı (\%93) hastaya plevral MM, 5 hastaya (\%7) peritoneal MM tanısı konuldu ve hastaların 18 'inin $(\% 25,4)$ Sarıhıdır, Karain ve Tuzköy'de ikamet ettiği karar verildi. Ortanca OS plevral MM için 16 ay (aralık: 1-133) ve peritoneal MM için 21 ay (aralık: 9-117) idi. Tanı anında 60 yaş ve altındaki hastalarda anlamlı olarak daha yüksek OS gözlendi $(p=0,014)$. Nevşehir Hastanesi'nde sadece 6 hasta $(\% 8,5)$ ve Kapadokya dışında 65 hastanın \%91,5’i teşhis edildi.

Sonuç: Çalışmamızda Kapadokya'daki güncel durum değerlendirilmiş̦tir. MM hastalarının OS son 30 yılda önemli ölçüde değişmemiştir. Hastaların yaklaşık \%90'ı tanı ve tedavi için il dıșına çıkmak zorunda kalmıșır. Bölgedeki mevcut durumu ve tedavi sonuçlarını değerlendirmek için ek araștırmalara ihtiyaç vardır.

Anahtar Kelimeler: Kapadokya, malign plevral mezotelyoma, malign peritoneal mezotelyoma

Cite this article as/Atıf: Aral IP, Beșiroğlu M, Aytaç Arslan S. Malignant Mesothelioma in Cappadocia: Data from Eight Regional Hospitals. İstanbul Med J 2020; 21(5): 337-43.

(c) Copyright 2020 by the University of Health Sciences Turkey, Istanbul Training and Research Hospital/istanbul Medical Journal published by Galenos Publishing House.

(C) Telif Hakkı 2020 Sağıı Bilimleri Üniversitesi Istanbul Ĕgitim ve Araştırma Hastanesi/Istanbul Tıp Dergisi, Galenos Yayınevi tarafından basılmıștır. 


\section{Introduction}

Malignant mesothelioma ( $\mathrm{MM}$ ) is a rare progressive fatal malignant tumour associated with asbestos (1). The median age of diagnosis is 74 years. MM is twice more frequent in males than in females due to the occupational exposure. The latent period from asbestos exposure to MM development is approximately $20-40$ years $(2,3)$. The overall survival (OS) is poor (4-6). The most effective method for preventing MM is to avoid its risk factors $(6,7)$.

Cappadocia is one of the most common places where MM has been observed worldwide $(5,6)$. This situation first emerged in 1975 with the individual efforts and self-sacrificing research of Baris et al. (810). A national mesothelioma registry unit is not available in Turkey. In 2015, the Ministry of Health's Cancer Control Department published the cancer statistics. According to these statistics, the incidence of agestandardised mesothelioma has been reported as 1.1/100.000 in males and $0.6 / 100.000$ in females. There is no separate title for the Cappadocia region in these statistics $(5,11)$.

The first epidemiological studies of mesothelioma in Turkey were conducted in 1970 by Baris et al. (8,9). In these studies, the incidence of MM in the Karain village was found to be very high. In the detailed evaluation, the data of the Kayseri State Hospital, which is the closest hospital to Karain, was examined and we found that almost all of these patients were treated as Tuberculosis and all of them died within a year. In 1975, Baris and his colleagues examined the Karain village, which had a population of 800 at that time and the incidence of mesothelioma was 1000 times higher than in the other regions. Similar results were obtained in Tuzköy, which is $40 \mathrm{~km}$ away from Karain (5). It was observed that $50 \%$ of the deaths in Karain, Sarıhıdır and Tuzköy were caused by MM (12). In Karain (Female/Male) 76/74, Tuzköy 54/51 and Sarıhıdır, 7/8 deaths were found to be caused by MM (13). Due to these findings, it was decided to evacuate Tuzköy-Karain and Sarıhıdır.

In this study, the data of 8 state hospitals in Cappadocia, one of the places where $\mathrm{MM}$ is most common, were examined. It had as aim to provide information regarding the current situation of MM. Specifically, the study aimed to investigate the demographic characteristics, adequacy of diagnosis and treatment facilities, OS and the factors affecting the OS of MM patients admitted to hospitals in the region.

\section{Methods}

In this study, patients who were admitted to local public hospitals in Cappadocia between 01.01.2007 and 25.09.2019 were evaluated retrospectively as patients with pleural or peritoneal MM. Patient interview information, patient files, and the electronic system data were used for the study. Local hospitals whose data were extracted from the electronic system are Acigol District Integrated Hospital, Avanos District Integrated Hospital, Derinkuyu District Integrated Hospital, Gülşehir District Integrated Hospital, Hacibektas District Integrated Hospital, Urgup State Hospital, Nevşehir State Hospital, Kozakli Physical Therapy and Rehabilitation Hospital. The data of the patients admitted to these 8 hospitals in the Cappadocia region were reviewed retrospectively. The study was conducted in accordance with the Helsinki Declaration and it was approved by the Ethics Committee of Nevșehir Governorship
Provincial Health Directorate in September 2019 (approval number: 26171210-020). Informed consent was obtained from all the patients or relatives (for exitus patients) before the analysis.

Demographic status of the patients, centre of MM diagnosis, access to treatment and the latest status were noted. The study included adult patients between the stages of 1 and 4 according to AJCC-8, who were undergoing curative/palliative treatment and had complete information. Patients whose pathology report details were not available and missing file and follow-up information were excluded from the study.

The primary endpoint of the study was the OS. The date of diagnosis was accepted as the starting date for the OS. The final check-in date for patients experiencing an OS endpoint is the exitus date for ex-patients. Most of the patients could not be diagnosed and treated in Cappadocia. The treatment details were not available in these patients' files data and electronic system. Therefore, the progression free survival (PFS) could not be calculated. The secondary endpoint of the study was to evaluate the current status of MM cases in Cappadocia and to determine the patients' access to diagnosis/treatment.

\section{Statistical Analysis}

SPSS ver. 24 was used in this study. The normality of the variables was evaluated using visual and analysis methods and non-parametric tests were used since the variables did not fit the normal distribution. Chisquare and Fisher's exact tests were used to determine the differences in the demographic characteristics of the patients. Spierman's rank correlation test was used for univariate correlation analysis. KaplanMeirer was used for univariate survival analysis and the log rank test was also used. In the multivariate analyses, Cox Regression test was used. Statistical significance was accepted as less than 0.05 .

\section{Results}

We evaluated 1497 medical record (It is not the number of patients- It is the number of entered diagnosis of mesothelioma into the electronic system). Only 71 patients who met the inclusion criteria were identified. These 71 patients were treated with curative/palliative treatment in the 8 different state hospitals in the Cappadocia region with the diagnosis of stage 1-4 MM between 01.01.2007 and 25.9.2019 retrospectively. The median follow-up period was 26 (range: 1-153) months. During the follow-up period, 55 patients (77.5\%) were ex and 16 patients (22.5\%) were alive. In our study, 39 patients (54.9\%) were females and 32 patients (45.1\%) were males. The median age of the patients at the time of diagnosis was 66 (range: 36-86) the years. There was only one patient who was under 45 years of age at the time of diagnosis. This patient was diagnosed with malignant pleural mesothelioma at the age of 36 and he is currently residing in Tuzköy. Sixty-six (93\%) patients were diagnosed with malignant pleural mesothelioma and 5 (7\%) patients with malignant peritoneal mesothelioma.

Only 6 patients (8.5\%) were diagnosed at Nevșehir Public Hospital. MM (91.5\%) of 65 patients were diagnosed outside Cappadoccia. Only 9 patients $(12.7 \%)$ received supportive treatment for curative purposes and 62 patients (87.3\%) received palliative support. Symptoms of patients admitted to the regional hospitals; 28 patients (39.4\%) had dyspnoea, 
18 patients (25.3\%) had general condition disorder, 10 patients (14.1\%) had pain, 4 patients (5.6\%) had acute renal failure, 4 patients (5.6\%) had hypertension, 2 patients (5.6\%) 2.8\% were admitted to psychiatry clinic with depression and 2 patients $(2.8 \%)$ presented with neurological findings ( 1 seizure +1 speech disorder). The stages of the patients at the time of admission to the hospital (not the moment of diagnosis); 6 (8.5\%) were operable, $55(77.4 \%)$ were inoperable and 10 (8.5\%) were metastatic. Thoracentesis was performed in $8(11.3 \%)$ patients, while paracentesis was performed in $13(18.3 \%)$ patients. In the Nevşehir Public Hospital, computer tomography (19.7\%) was administered to 14 patients, of which 9 (12.7\%) were curative. There were no oncology clinics in the other 7 hospitals. Besides, there is no radiotherapy centre in Cappadocia.

When the patients were examined in terms of their place of residence, 21 patients (29.6\%) were examined in Urgup (Karain and Sarıhıdır were not included) and nineteen patients (26.8\%) in Gülșehir (Tuzköy were not included). It was observed that 18 (25.4\%) of the patients were residing in Sarıhıdır, Karain and Tuzköy with the decision of evacuation, but not completely separated (2 patients resided in Karain, 6 patients were residing in Sarıhır, 10 patients were still residing in Tuzköy) (Figure 1). Patient data are summarised in Table 1.

Another remarkable rate was the need for psychiatric support. The 26 (37.1\%) patients received medical treatment for depression and anxiety.

Median OS was 16 months (range: 1-133) for pleural MM and 21 months (range: 9-117) for peritoneal MM. The OS difference between pleural MM and peritoneal MM was not statistically significant $(p=0.23)$. The one-year OS for pleural MM was $60.9 \%$ and the 2 -year OS was $31 \%$. For peritoneal MM, the one-year OS is 60\% and 2-year OS is $40 \%$ (Figure 2).

There were 7 patients with a survival of more than 5 years. The survival of these patients were 133 months (pleural MM), 117 months (peritoneal MM), 115 months (pleural MM), 101 months (pleural MM), 96 months (pleural MM), 87 months (peritoneal MM) and 86 months (pleural MM) months. For pleural $\mathrm{MM}$, gender $(\mathrm{p}=0.89)$, right or left pleural disease $(p=0.84)$, diagnosis and treatment $(p=0.38)$ being performed outside or

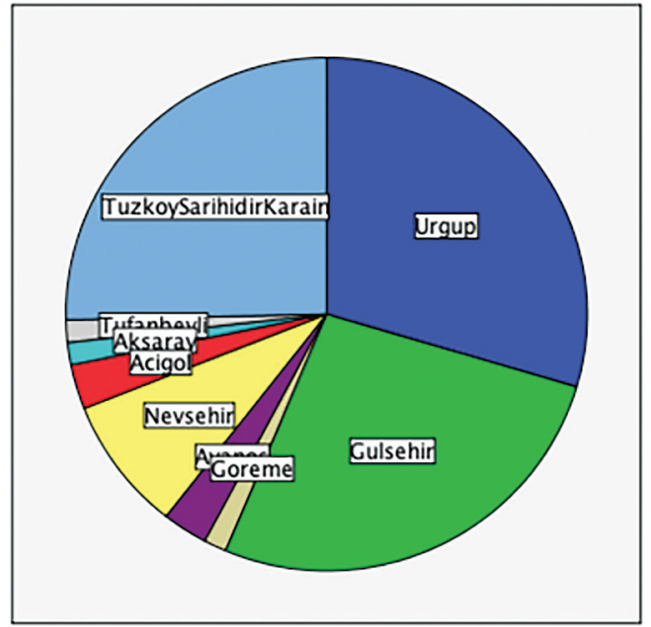

Figure 1. Centres where the patients resided at the time of admission within the province and patients still living in Tuzköy-Sarıhıdır-Karain $(p=0.33)$ did not significantly affect OS (Figure 3).

The relationship between pleural MM OS and age at diagnosis was investigated. The median OS value of patients aged 60 years or less at the time of diagnosis was 23.9 (range: 4-133), whereas the median os value of patients over 60 years of age was 13.4 (range: 1 -117) $(p=0.014)$ (Figure 4).

\section{Discussion}

In the current study, $71 \mathrm{MM}$ patients who were admitted to 8 different hospitals in Cappadocia in the last 12 years were identified. Sixty-six (93\%) of them had a pleural origin and 5 (7\%) had a peritoneal origin. Median OS was 16 months for pleural MM and 21 months for peritoneal $\mathrm{MM}$. The OS of the patients included in our study was only adversely affected by advanced age. The gender, pleural or peritoneal origin, right and left lung location, diagnosis and treatment in-province or out-ofprovince and residing in high-risk endemic regions did not significantly

\section{Table 1. Patient details}

\begin{tabular}{|c|c|c|}
\hline \multirow{2}{*}{ Gender } & Female & $39(54.9 \%)$ \\
\hline & Male & $32(45.1 \%)$ \\
\hline \multirow{2}{*}{ Primer } & Malignant pleural mesothelioma & $66(90 \%)$ \\
\hline & Malignant peritoneal mesothelioma & $5(7 \%)$ \\
\hline \multirow{2}{*}{ Treatment } & Curative & $9(12.7 \%)$ \\
\hline & Palliative & $62(87.3 \%)$ \\
\hline \multirow{7}{*}{ Symptoms } & Dyspnoea & $28(39.4 \%)$ \\
\hline & General condition disorder & $18(25.3 \%)$ \\
\hline & Pain & $10(14.1 \%)$ \\
\hline & Acute renal failure & $4(5.6 \%)$ \\
\hline & HT & $4(5.6 \%)$ \\
\hline & Depression & $2(2.8 \%)$ \\
\hline & Neurologic finding & $2(2.8 \%)$ \\
\hline \multirow{10}{*}{ Residence } & Sarıhıdır & $6(8.4 \%)$ \\
\hline & Tuzköy & $10(14.1 \%)$ \\
\hline & Karain & $2(2.8 \%)$ \\
\hline & Ürgüp & $21(29.1 \%)$ \\
\hline & Gülșehir & $19(26.8 \%)$ \\
\hline & Nevșehir (Centre) & $6(8.5 \%)$ \\
\hline & Avanos & $2(2.8 \%)$ \\
\hline & Acıgöl & $2(2.8 \%)$ \\
\hline & Aksaray & $1(1.4 \%)$ \\
\hline & Tufanbeyli & $1(1.4 \%)$ \\
\hline \multirow{2}{*}{ Diagnosis } & In Cappadoccia & $6(8.5 \%)$ \\
\hline & Outer centre & $65(91.5 \%)$ \\
\hline \multirow{3}{*}{ Stage } & Operable & $6(8.5 \%)$ \\
\hline & In-operable & $55(77.4 \%)$ \\
\hline & Metastatic & $10(14.1 \%)$ \\
\hline \multirow{2}{*}{ Last status } & Ex & $55(77.5 \%)$ \\
\hline & Alive & $16(22.5 \%)$ \\
\hline
\end{tabular}




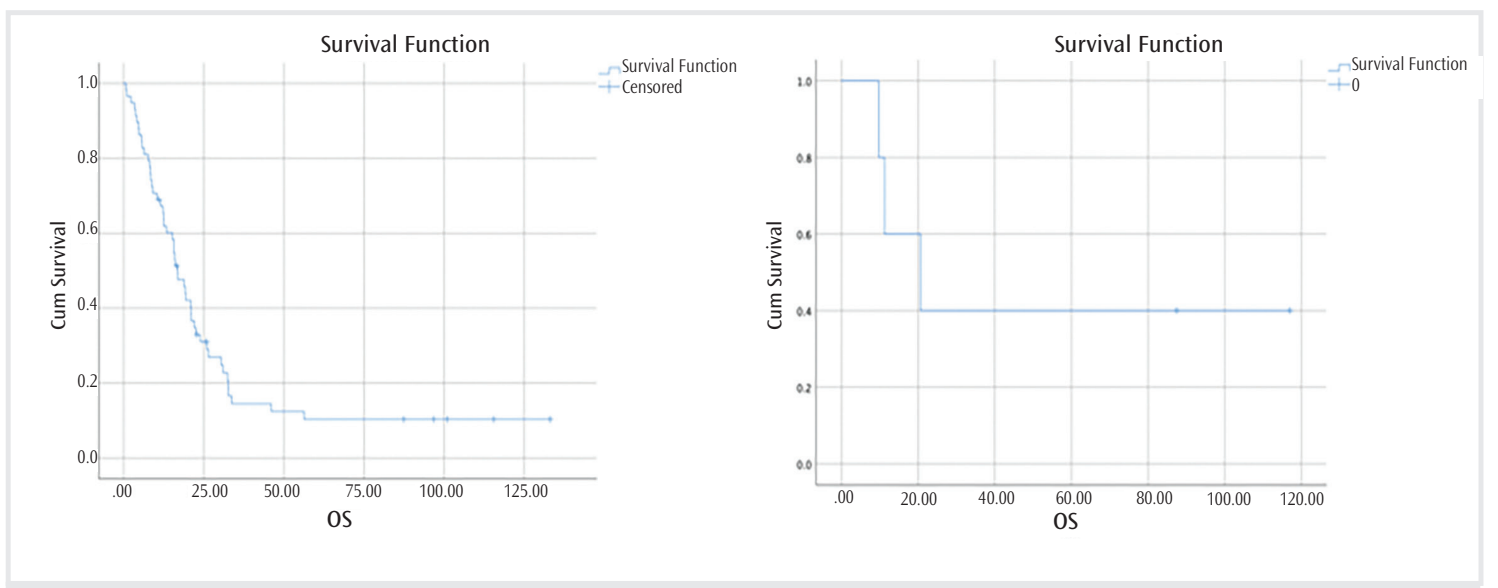

Figure 2. Overall survival analysis of patients with malignant pleural mesothelioma and malignant peritoneal mesothelioma, respectively
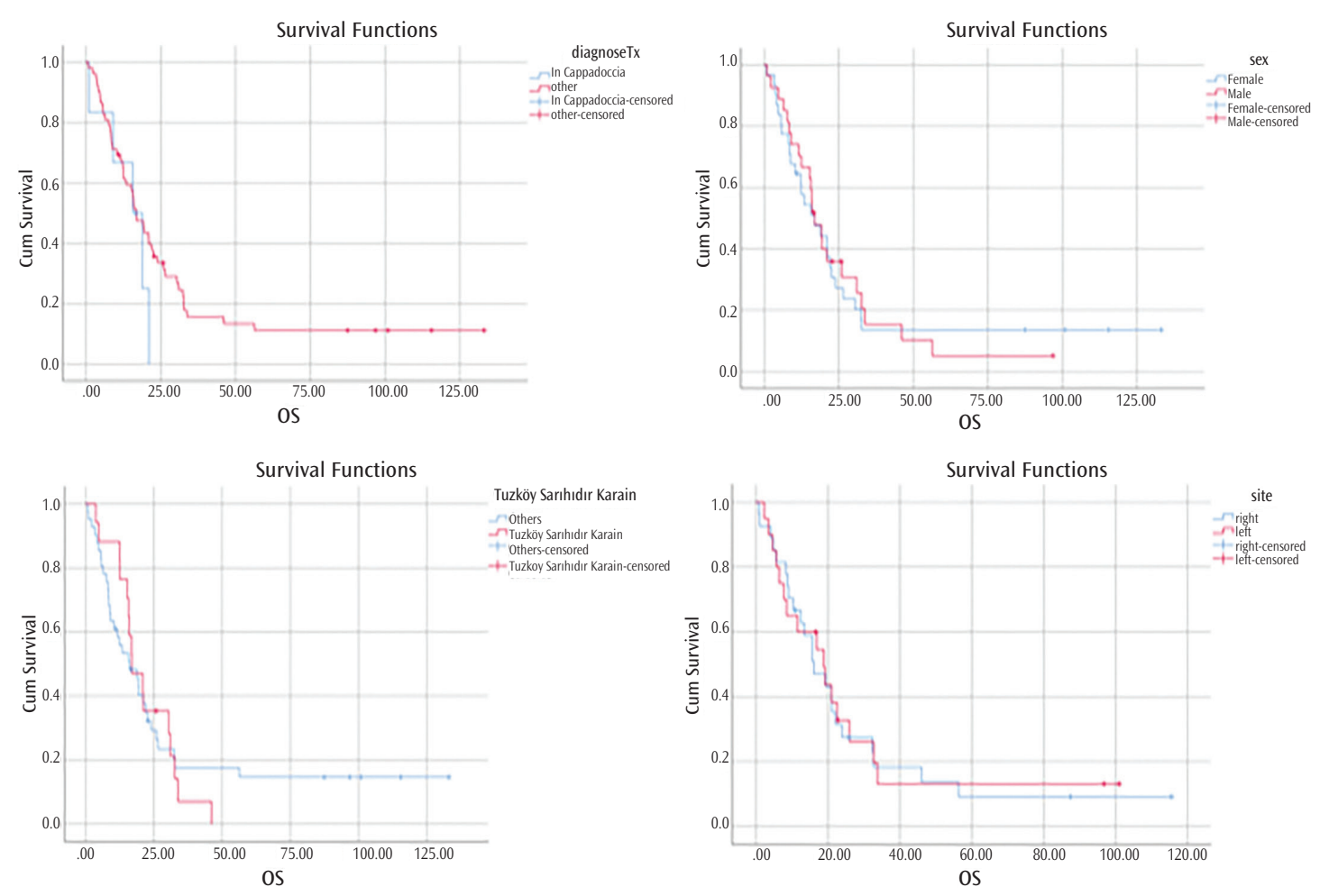

Figure 3. Detailed analysis of variables with pleural MM and OS

MM: Malignant mesothelioma, OS: overall survival

affect 0 . When evaluated in terms of access to health services, 90\% of the patients could not have been diagnosed or treated in Cappadocia. Palliative treatment is the only available facility in the region.

The median OS of the patients were 16 months for pleural MM and 21 months for peritoneal MM. Baris (14) evaluated $185 \mathrm{MM}$ patients in 1980 and determined the period from onset of symptoms to death as approximately 18 months. Selçuk et al. (15) evaluated 135 pleural MM patients in 1992. In their evaluation, the median os was found to be 13.5 months for erionitis-related MM and 21.5 months for MM associated with other asbestos dust. Although the patients in the diagnosis stages of our study do not know the treatments they receive in detail, it is seen that patients' OS has not changed dramatically in the last 40 years.

It has been reported in the literature that MM is more common in men $(3,5)$. In this study, 39 (54.9\%) of the patients were females and 32 (45.4\%) were males. This data is not consistent with the literature, but it is consistent with the first study conducted in Cappadocia (5). In addition, male gender was defined as a negative prognostic factor (16-18). In the SEER analysis of 14,228 diseases published by Taioli et al. (3) in 2014, the OS of women was reported to be 3 times higher than that of men. In the current study, no significant effect of gender on OS was observed. In this 


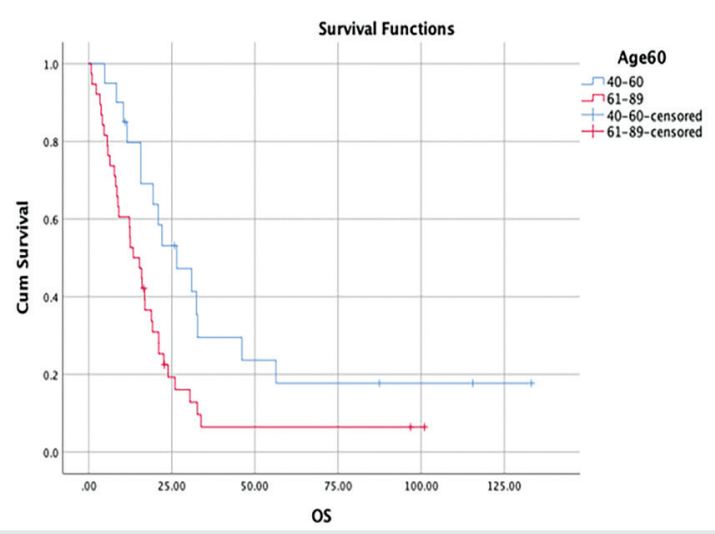

Figure 4. Relationship between patient age and OS in pleural MM MM: Malignant mesothelioma, OS: overall survival

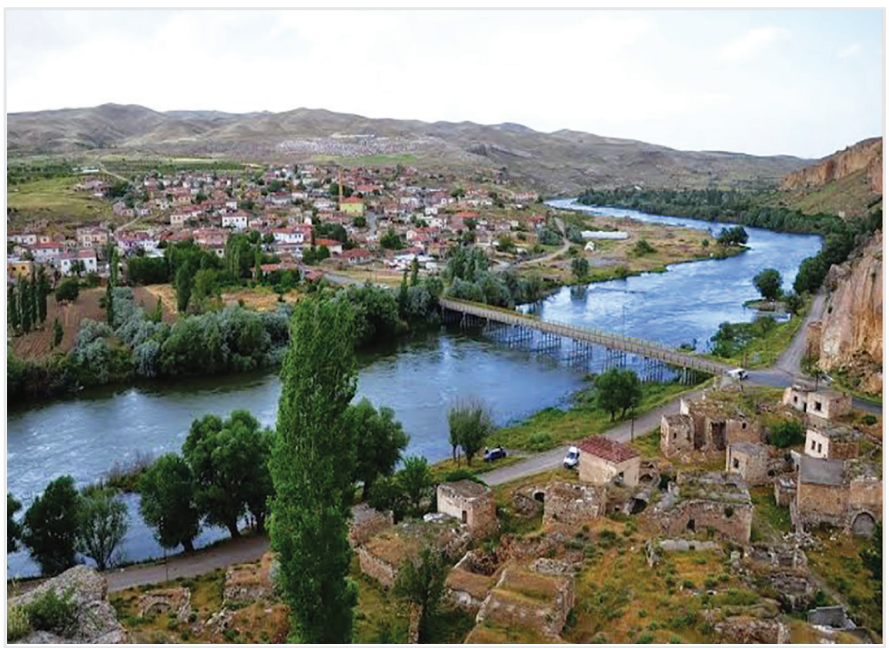

Figure 5. The area to the right of Kızılırmak is the old Sarıhıdır. The area on the left is the new settlement

state, this data are consistent with the retrospective study of Koyuncu et al. (19), which evaluated 60 patients with MM.

In case of intensive exposure, MM develops at an earlier age (20). In the preliminary cross-sectional studies in Cappadocia, it has been reported that there are MM patients in their 20s (5). In our study, there was one case diagnosed under the age of 40 and this case has lived in Tuzköy. Also, there were 5 cases under 50 years of age. In many studies, advanced age has been defined as a poor prognostic factor (16-18). In our study, lower OS was obtained in elderly patients.

Peritoneal Mesothelioma constitutes $7 \%-30 \%$ of all MM cases (8). It has been reported that peritoneal MM has better survival than pleural MM (17). In this study, peritoneal mesothelioma accounted for $7 \%$ of cases. Median OS of patients with pleural MM was 16 months (range: 1-133), while the median survival of patients with peritoneal MM was 21 (range: 9 -117) $(p=0.23)$. In addition, 2 (28.5\%) of 7 patients with OS values greater than 5 years were diagnosed with peritoneal MM and these 2 patients are still alive. Although peritoneal MM patients had higher median survival and OS status higher than 5 years, the difference between pleural MM was not significant. This result may be due to the small number of peritoneal MM patients.
Another issue we want to consider is the access to health services for patients and the evaluation of the current cases of MM. As it is known, Cappadocia is an endemic MM region. When the endemic MM cases were examined, no high incidence was observed in any region as much as in Cappadocia $(5,7)$. For example, endemic mesothelioma was reported in the Sicilian region of Italy between 1980 and 1997 due to the Etna Volcanic Mountain and the total number of cases in this region was 17 (10 men, 7 women). The population of the region is 23.000 for that period (21). Due to serpentine-coated roads, an increase in MM cases was reported in Kaleonia and 109 cases were observed between 1984 and 2008 (22). In Cappadocia, 50\% of deaths in high-risk areas have been reported to be caused by $\mathrm{MM}(5)$.

This endemic MM was identified as zeolite stones used in house construction in these three villages (13). The villages were evacuated to prevent asbestos exposure and to reduce MM cases. There are currently three problems in this regard. First, the high-risk areas are not fully evacuated. It was found that 18 of 71 patients in our study still live in Karain-Tuzköy and Sarıhıdır. They are still inhabitants of these villages. Secondly, erionite was found not only in the stones of the houses, but also in the air of these villages (23). Small amounts of erionite inhalation may be sufficient for MM development. For example, in an animal experiment in rats, $\mathrm{MM}$ developed in 27 out of 28 rats inhaling erionite; MM developed in 11 of 648 rats in other asbestos types (24). It is located very close to the new settlements - the old ones (Figure 5). Some of the inhabitants of Tuzköy-Karain and Sarıhıdır have evacuated their houses and moved to the new settlement. However, since the newly settled houses are close to the old ones, the extent of exposure due to increased erionite detected in the air continues and the current status of MM incidence should be examined separately. The third situation is the long latent period between asbestos exposure and MM development. Long-term follow-up of patients is required even if the sites are evacuated. Data on families migrating to Europe are available in the literature. In a study conducted in Sweden, it was found that increasing cases of malignant pleural mesothelioma (MPM) originate from families migrating from the Karain. The incidence of MPM was 639/100,000 per year for males and 1,267/100,000 per year for females. In this group, the mortality rate caused by MPM was $78 \%$. These rates are compared with the Swedish population; 135.5 times for men and 1336.3 times higher for women (25). However, there is insufficient data on the final status of people moving out of Cappadocia in Turkey.

The development of MM is not only related to exposure to asbestos, but also individual carcinogenesis susceptibility $(7,13,26)$. In the analysis of workers exposed to crocidolite asbestos in South Africa, $4.6 \%$ of them exitus due to MM. Increased exposure is a risk factor for the development of MM, but some of the exposed patients have no disease (10). Dogan et al. (27) reported in 2006 that these endemic and dense MM cases seen in Cappadocia were not only caused by erionite, but also by genetic predisposition. In a study conducted in Karain, the last 6 generations of the patients were examined and it was argued that autosomal dominant mechanisms could play a role. Another case that supports this issue is that, there is a relatively low rate of MM cases in Karlık village (where erionite is detected) which is $4 \mathrm{~km}$ away from Karain (28). Therefore, further studies are needed to determine the extent to which 
the incidence of $\mathrm{MM}$ decreases with reduced asbestos exposure and to what extent genetic predisposition is effective in this endemic.

There are a limited number of articles describing the current state of the literature in Cappadocia. There is a need for studies on the effectiveness of the measures taken and the treatment and response situations. The reason for this limitation is that patients are still unable to receive treatment in their provinces and they are distributed to different centres such as İstanbul, Ankara, Kayseri or Europe in accordance with their social support. This is an important challenge that reveals the current status of MPM in Cappadocia, the effectiveness of the treatments applied and the latest status of patients. Evaluation of the patients in one easy-to-reach centre may benefit the patient. In addition, sharing results from this region with the highest incidence of this rare disease worldwide will contribute to the literature. For example, Carbone et al. (13), in our region as a result of research, the first mineral fibre carcinogenesis modulating gene could be identified: BAP-1, in the early 2000s $(5,6)$.

There are some important limitations of our study. First of all, the study is retrospective. The stages of diagnosis, treatment details and response to treatment are unknown. Only patients whose pathology report was available were included in the study, and treatment details were not noted in detail in many files. Therefore, PFS could not be calculated. However, our study covers all state hospitals in Cappadocia. We think that the data obtained by examining the records of 8 different hospitals in the region can give an idea regarding the current situation in Cappadocia.

\section{Conclusion}

The OS of MM patients has not changed dramatically in the last 30 years. Approximately $90 \%$ of patients had to go out of the province for diagnosis and treatment. Additional studies are needed to evaluate the current situation and treatment results in the region.

\section{Acknowledgment}

I would like to thank to Özlem Özkan for her valuable contributions of for photo and information about Sarıhıdır and to thank Kübra Aygün, the chemotherapy nurse in Nevsehir State Hospital, for helping to reach patients who did not come to follow-up.

\section{Ethics}

Ethics Committee Approval: The study was conducted in accordance with the Helsinki Declaration and it was approved by the Ethics Committee of Nevşehir Governorship Provincial Health Directorate in September 2019 (approval number: 26171210-020).

Informed Consent: Informed consent was obtained from all the patients.

Peer-review: Externally peer-reviewed.

Authorship Contributions: Surgical and Medical Practices - I.P.A., M.B.; Concept - I.P.A., S.A.A.; Design - I.P.A.; Data Collection or Processing I.P.A.; Analysis or Interpretation - M.B., S.A.A.; Literature Search - I.P.A., M.B., S.A.A.; Writing - I.P.A.
Conflict of Interest: No conflict of interest was declared by the authors.

Financial Disclosure: The authors declared that this study received no financial support.

\section{References}

1. Kim J, Bhagwandin S, Labow DM. Malignant peritoneal mesothelioma: a review. Ann Transl Med 2017; 5: 236

2. Bibby AC, Tsim S, Kanellakis N, Ball H, Talbot DC, Blyth KG, et al. Malignant pleural mesothelioma: an update on investigation, diagnosis and treatment. Eur Respir Rev 2016; 25: 472-86.

3. Taioli E, Wolf AS, Camacho-Rivera M, Flores RM. Women with malignant pleural mesothelioma have a threefold better survival rate than men. Ann Thorac Surg 2014; 98: 1020-4.

4. Robinson BW, Musk AW, Lake RA. Malignant mesothelioma. The Lancet 2005; 366: 397-408

5. Salih Emri. The Cappadocia mesothelioma epidemic: its influence in Turkey and abroad. Ann Transl Med 2017; 5: 239.

6. Carbone M, Kanodia S, Chao A. Consensus Report of the 2015 Weinman International Conference on Mesothelioma. J Thorac Oncol 2016; 11: 1246-62.

7. Metintas M, Hillerdal G, Metintas S, Dumortier P. Endemic malignant mesothelioma: exposure to erionite is more important than genetic factors. Arch Environ Occup Health 2010; 65: 86-93.

8. Baris YI, Sahin AA, Ozesmi M. An outbreak of pleural mesothelioma and chronic fibrosing pleurisy in the village of Karain/Urgüp in Anatolia. Thorax 1978; 33: 181-92.

9. Baris I, Artvinli M, Sahin A, Savas T, Erkan ML. [Occurrence of pleural mesothelioma. Chronic fibrosing pleurisy and calcified pleural plaques in Turkey in relation with environmental pollution by mineral fibers (author's transl)]. Rev Fr Mal Respir 1979; 7: 687-94.

10. Artvinli M, Bariş YI. Malignant mesotheliomas in a small village in the Anatolian region of Turkey: an epidemiologic study. J Natl Cancer Inst 1979; 63: $17-22$.

11. TÜIK. "Ölüm Nedeni İstatistikleri, 2014". last accessed date: 16.01.2017. Available from: http://www.tuik.gov.tr/PreHaberBultenleri.do?id=18855

12. Bariş B, Demir AU, Shehu V, Kisacik G, Bariş YI. Environmental fibrous zeolite (erionite) exposure and malignant tumors other than mesothelioma. J Environ Pathol Toxicol Oncol 1996; 15: 183-9.

13. Carbone M, Emri S, Dogan AU, Steele I, Tuncer M, Pass HI, et al. A mesothelioma epidemic in Cappadocia: scientific developments and unexpected social outcomes. Nat Rev Cancer 2007; 7: 147-54.

14. Baris $Y$. The clinical and radiological aspects of 185 cases of malignant pleural mesothelioma. IARC Sci Publ 1980; 30: 937-47.

15. Selçuk ZT, Cöplü L, Emri S, Kalyoncu AF, Sahin AA, Bariş YI. Malignant pleura mesothelioma due to environmental mineral fiber exposure in Turkey. Analysis of 135 cases. Chest 1992; 102: 790-6.

16. Moore AJ, Parker RJ, Wiggins J. Malignant mesothelioma. Orphanet J Rare Dis 2008; 3: 34.

17. Amin W, Linkov F, Landsittel DP, Silverstein JC, Bashara W, Gaudioso, et al Factors influencing malignant mesothelioma survival: a retrospective review of the National Mesothelioma Virtual Bank cohort. F1000 Res 2018; 7: 1184.

18. Taioli E, Wolf AS, Camacho-Rivera M, Kaufman A, Lee DS, Nicastri D, et al. Determinants of Survival in Malignant Pleural Mesothelioma: Surveillance, Epidemiology, and End Results (SEER) Study of 14,228 Patients. PLoS One 2015; 10: e0145039. 
19. Koyuncu A, Koksal D, Ozmen O, Demirag F, Bayiz H, Aydogdu K, et al. Prognostic factors in malignant pleural mesothelioma: a retrospective study of 60 Turkish patients. J Cancer Res Ther 2015; 11: 216-22.

20. Dragani TA, Colombo F, Pavlisko EN, Roggli VL. Malignant mesothelioma diagnosed at a younger age is associated with heavier asbestos exposure. Carcinogenesis 2018; 39: 1151-6.

21. Soffritti M, Minardi F, Bua L. First experimental evidence of peritoneal and pleural mesotheliomas induced by fluoro-edenite fibres present in Etnean volcanic material from Biancavilla (Sicily, Italy). Eur J Oncol 2004; 9: 169-75.

22. Baumann F, Maurizot P, Mangeas M, Ambrosi JP, Douwes J, Robineau B. Pleural mesothelioma in New Caledonia: associations with environmental risk factors. Environ Health Perspect 2011; 119: 695-700.

23. Sluis-Kremer GK. Asbestos disease at low exposure after long residence times. Ann. NY Acad Sci 1991; 643: 182-93.
24. Wagner JC Skidmore JW, Hill RJ, Griffiths DM. Erionite exposure and mesotheliomas in rats. Br J Cancer 1985; 51: 727-30.

25. Metintas M, Hillerdal G, Metintas S. Malignant mesothelioma due to environmental ex- posure to erionite: follow-up of a Turkish emigrant cohort. Eur Respir J 1999; 13: 523-6.

26. Roushdy-Hammady I, Siegel J, Emri S, Testa JR, Carbone M. Geneticsusceptibility factor and malignant mesothelioma in the Cappadocian region of Turkey. Lancet 2001; 357:444-5.

27. Dogan AU, Baris YI, Dogan M, Emri S, Steele I, Elmishad AG, et al. Genetic predisposition to fiber carcinogenesis causes a mesothelioma epidemic in Turkey. Cancer Res 2006; 66: 5063-8.

28. Metintas M, Hillerdal G, Metintas S, Dumortier P. Endemic malignant mesothelioma: exposure to erionite is more important than genetic factors. Arch Environ Occup Health 2010; 65: 86-93. 